\title{
Farmers Market Participation Decision and Intensity of Participation in Butter and Cheese Marketing: The Case of Loma Woreda, Dawuro Zone Southern Ethiopia
}

\author{
Betela Beyene Tsegaye Lijalem \\ Department of Agribusiness and Value Chain Management, College of Agriculture, \\ Wolaita Sodo University, \\ P.O.Box. 138
}

\begin{abstract}
This study was conducted with the main objective of; identify determinants of farmers' market participation and level of participation in the study area. About 138 smallholder butter and cheese producers were selected randomly from six Kebele administrations proportionally. Both qualitative and quantitative types of data were used. Primary data was collected by using both close ended and open ended (semi- structured) questionnaire and personal interview, focus group discussion and key informant interview was used to collect the data. Heckman two stage models were used to analyze the data. The result of probit model indicated that farmers' market participation on butter and cheese is significantly affected by gender, quantity of milk yield produced per day, family size, access to extension service, types of dairy cows' breed owned by households and access to credit. While farmers' participation decision on volume of milk value addition is significantly affected by gender, family size, education level of household, distance nearest to market, farmers membership in cooperatives, types of breed owned by household, access to extension service, access to credit, quantity of milk produced per day and consumers' quality preference on value added dairy products. In general, policy initiatives aiming at increasing farmers' access to dairy technologies, improving market information, road, access extension service, access to credit and cooperative development are recommended to step up the development of dairy sector particularly butter and cheese value chain in the study area.
\end{abstract}

Keywords: Mills Ratio, Heckman two stages, Probit, Value Chain Analysis

DOI: $10.7176 / \mathrm{JMCR} / 54-02$

Publication date:March $31^{\text {st }} 2019$

\section{INTRODUCTION}

\subsection{Background of the Study}

Currently the cattle population is estimated to be about 52 million (MoA, 2010), out of which female cattle (cow or heifers) constitute about 55.4 percent. About $99.28 \%$ of the total cattle are local breeds and the remaining are hybrid and exotic breeds (CSA, 2009). Ethiopia holds the largest livestock population in Africa estimated to about 52.13 million cattle, 24.2 million sheep and 22.6 million goats (CSA, 2012). The total annual national milk production in Ethiopia comes from about 10 million milking cows and is estimated by 3.2 billion liters that is, 1.54 $\mathrm{L} /$ cow on average (CSA, 2012). About $83 \%$ of the total milk production in Ethiopia is from cows and the remainder is from goats and camels in certain regions particularly in pastoralist areas (LDMPS, 2007). As dairying plays significant role in the lives of the urban and peri-urban poor households (Yitaye et al., 2007), promotion of the dairy sector in Ethiopia can therefore contribute significantly to poverty alleviation as well as availability of food and income generation.

In Ethiopia, dairy value chain entailed about 500,000 smallholder rural farmers who produce about 1,130 million liters of milk of which 370 million liters of raw milk, 280 million liters of butter and cheese and 165 million liters is consumed by the calves (Mohammed, 2009). The private sector to the increased demand for dairy is expected to be significant, the small-scale household farms in the highlands hold most of the potential for dairy development (Mohammed et al., 2004). Jabbar (2009) stated that the analysis of a value chain encompasses wider issues than supply chain, which only shows the physical flow of goods or services from production to consumption through intermediate stages of value addition.

The SNNPR has $23.5 \%$ of Ethiopia's milking cows and produces 27 of the Percentage Share of Milk Production. The processing and trade of dairy products, especially soured butter, dominates the dairy sector. Some of the butter is used for home consumption, and the surplus is for sale to small traders who transport it to urban areas for distribution by wholesalers and retailer butter traders. Ayib, a soft cottage cheese, is produced on the farm from sour buttermilk, for home use and for sale (LMD, 2013). Dawuro Zone is one of SNNPR with the livestock resource of 411.54 thousand cattle, 168.02 thousand sheep's 125.08 thousand goats, 39.08 thousand equines and 219.87 thousand poultry. 


\subsection{Statement of the Problem}

The livestock sector in general and the milk production in particular do not provide the expected contribution to the national income despite their large numbers due to several factors. The development of the milk sector in the country is hindered by a number of technical, institutional and socio-economic constraints. The growth in milk production has been slow and the annual milk production is estimated to be 1,089,488,251 litters (MoARD, 2007) which don't meet even the domestic demand for milk production. The traditional milk production system, which is dominated by indigenous breeds of low genetic potential for milk production, accounts for about 97 percent of the country's total annual milk production (Felleke, 2003). Ethiopia's dairy value chain is thus constrained by low milk productivity at the farm level, inefficient logistics to link producers and processors, and low real demand even if demand does exceed supply (LMD, 2013).

Promoting on-farm value addition to milk products is believed to be useful for poverty reduction through creating income generating opportunities to the rural poor. Nevertheless, farmers' participation in milk value addition is perceived to be generally low (Berhanu et al; 2011). Lemma et al. (2008) and Yilma et al. (2011) reported weak linkages among the different actors in the dairy value chain are some of the important factors that contribute to the poor development of Ethiopia's dairy sector. Loma Woreda is the areas in which this research was conducted. Dairy is one of potential sector in Loma Woreda in Dawuro Zone which has a significant contribution to the livelihood of small scale farmers in the area thereby contributing to the income of the majority of smallholder producers as well as ensuring of food security. Since value chain contributes to the reduction of poverty through the improvement of household incomes; this study was attempted to contribute by filling the information gap along butter and cheese value chain in the study area. This is quite necessary for the policy intervention and improvement of rural economic sector especially rural livelihood and social welfare there by contributing to the rural income generation. This study was attempted to address the objective of identify factors affecting market participation decision and intensity of farmers' participation in butter and cheese marketing

\subsection{Definitions and Basic Concepts}

Value chain actors: Are actors those involved in supplying inputs, producing, processing, marketing and consuming agricultural products (Getnet, 2009). They can be those that directly involved in the value chain (rural and urban farmers, cooperatives, processors, traders, retailers, cafes and consumers) or indirect actors who provide financial or non financial support services, such as credit agencies, business service and government, researchers and extension agents.

\subsubsection{Value Chain Analysis and Its Importance}

Value chain analysis provides useful information on structure linkages, actors, and dynamics. It helps to identify where, how, why, and by whom value is added and created along the chain, as well as how changes could result in improved performance (Hawkes and Ruel, 2011). It overcomes a number of important weaknesses of traditional sector analysis which tends to be static and suffers from the weakness of its own bounded parameters. It plays a key role in identifying the distribution of benefits of actors in the chain. That is, through the analysis of margins and profits within the chain, one can determine who benefits from participation in the chain and which actors could benefit from increased support or organization.

\subsubsection{Value addition}

Value added related to quality, costs, delivery times, delivery flexibility, innovativeness, etc. The size of value added is decided by the end-customer's willingness to pay (Fleming, 2005). Value addition results from diverse activities including bulking, cleaning, grading, and packaging, transporting, storing and processing while value added is the difference between revenue and the cost of externally sourced material and service inputs is a node's value added (Anandajayasekeram and Berhanu, 2009). As a given commodity flows through the different segments along the chain, value is created.

\section{METHODOLOGY OF THE STUDY}

\subsection{Description of Study Areas}

The Dawuro Zone covers total area of 4436.7 sq. $\mathrm{km}^{2}$ and lies between 6.59-7.34 degree north latitude and 36.68 to 37.52 degree east longitudes, with an elevation ranging 501-3000m (Mathewos, 2008). The zone has 5 Woredas' (Mareka, Loma, Essera, Tocha and Gena Bossa Woredas) with a total population of 398,796. Regarding the AgroEcology, $55.6 \%$ is kolla, $41.4 \%$ is Weyna-Dega and 3\% is Dega. The annual mean temperature ranges between 15.1 to $27.5^{\circ} \mathrm{c}$. The average annual rainfall ranges from 1201 to $1800 \mathrm{~mm}$. The livestock resource of the zone was estimated to be 313,094 cattle, 113,554 sheep, 45,703 goats, 7,081 horses, 1,934 mules, 5,064 donkey, and 157,996 chicken and 28,557 traditional hives (CSA 2006). This study was conducted in Loma Woreda of Dawuro Zone, Southern Nation Nationalities and People Region (SNNPR). Altitude ranges or lies between 1160 and $2300 \mathrm{~m}$ above sea level and receives $1400 \mathrm{~mm}-1600 \mathrm{~mm}$ rainfall annually. The mean temperature ranges from $15.1^{\circ} \mathrm{C}$ to $27.5^{\circ} \mathrm{C}(\mathrm{DFEDD}, 2013)$. 


\subsection{Sampling Procedure and Sample Size Determination}

Multi-stage sampling technique was used to conduct this study. Dawro zone has five Woreda administrations and one town administration. Loma Woreda was selected purposively as the study area based on the extent of farmers' participation on butter and cheese marketing. Six kebele administrations were selected purposively. These are Yallo , Gessa, Mida zalo, Loma balle, Tula kae and Fulassa Balle kebele adminstration. Finally, 138 sample households were determined by using the simple random sampling techniques. Thus, for the populations that are large, Cochran (1963:75) developed the Equation 1 to yield a representative sample for proportions.

$n=\frac{z^{2} p(1-p)}{d^{2}}$

Where $\mathrm{n}_{0}$ is the sample size, $\mathrm{Z}^{2}=3.84$ is the abscissa of the normal curve that cuts off an area $\alpha$ at the tails ( $1-\alpha$ equals the desired confidence level, e.g., 95\%)' $d$ is the desired level of precision which is $0.05, p$ is the estimated proportion of an attribute that is present in the population at $10 \%$ or 0.1 and $q$ is $1-p(1-0.1)=0.9$. The value for $Z$ is found in statistical tables which contain the area under the normal curve. This can be estimated as:

$N=\frac{1.96^{2} 0.1(1-0.1)}{0.05^{2}}=138$

Table 1: Sampling for producers

\begin{tabular}{llll}
\hline Kebele Administrations & Dairy producer households & Proportion & Sample household \\
\hline Dissa & 540 & 0.17 & 23 \\
Tulema & 568 & 0.18 & 24 \\
Mida zalo & 504 & 0.160 & 21 \\
Loma balle & 517 & 0.16 & 21 \\
Tula kae & 448 & 0.14 & 19 \\
Fulassa Balle & 603 & 0.19 & 25 \\
Total & 3180 & & 138 \\
\hline
\end{tabular}

Source: Own computational work (2017)

\subsection{Types, Sources and Method of Data Collection}

Both quantitative and qualitative data were used. Quantitative data permit a more objective assessment and facilitate an assessment of larger-scale patterns, trends and relationships among different value chain actors. The qualitative research tools were used to check the reliability of data collected by questionnaire. The secondary sources of data were journals, books, Internets browsing, Reports of national policy, regional, zonal and woreda CSA. Generally, well-developed structured questionnaire and check lists were prepared.

\subsection{Methods of Data Analysis}

\subsubsection{Econometrics analysis} Intensity of Market participation

To analyze producers' market participation on butter and cheese and extent of market participation two step procedures was used. Heckman (1979) developed Heckman model which has important role in solving a selectivity bias to analyze factors affecting producers' market participation decision in first step and the extent of participation in second step. The choice of this model is based on the fact that the decision market participation is discreet; it is either one participates market or not. Therefore, Heckman two step procedure specifications can be written as:

$$
\begin{gathered}
Y *=Z^{\prime} \alpha+\Sigma 1 \\
Y=1 \text { If } Y *>0
\end{gathered}
$$

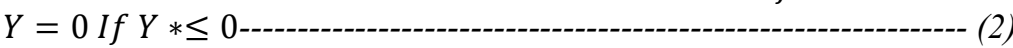

Where,

$\mathrm{Y} *=$ latent (unobservable) variable representing farmers' discrete decision whether to add values to milk or not $Z^{\prime}=$ vector of independent variables hypothesized to affect farmer's decision to add values to milk

$\alpha=$ vector of parameters to be estimated which measures the effects of explanatory variables on the farmer's decision

$\varepsilon 1=$ normally distributed disturbance with mean $(0)$ and standard deviation of $\delta 1$, and captures all unmeasured variables

$\mathrm{Y}=$ dependent variable which takes on the value of 1 if the farmers add values on milk and 0 otherwise. Probit parameter estimate does not show by how much a particular variable increases or decreases the likelihood of adding values to milk. Therefore, marginal effects of independent variables on the likelihood of farmers to add value on milk should be considered. Finally, the log likelihood function which is maximized to obtain parameter estimates and corresponding marginal effects is given as:

$\operatorname{Ln} L=\left(\frac{\alpha}{Y}, Z\right)=\sum_{y=1} \ln \left(\Phi\left(Z^{\prime} \alpha\right)+\sum_{y=0} \ln \left(1-\Phi\left(Z^{\prime} \alpha\right)-\right.\right.$ 
Conditional on participation decisions, the variables determining level of participation are modeled using the second-stage Heckman selection model (Heckman, 1979). The Heckman selection equation is specified as:

$Z_{i} *=W i^{\prime} \alpha+\varepsilon 2$

$Z_{i}=Z_{i} *$ if $Z_{i} * \geq 0$

$Z_{i}=0$ if $Z_{i} * \leq 0$

Where,

$Z i *=$ latent variable representing the desired or optimal level of butter and cheese marketing which is observed if

$Z i^{*}>0$ and unobserved otherwise

$Z i=$ observed level of market participation

$W i=$ vector of covariates for unit i for selection equation which is a subset of $Z$

$\alpha=$ vector of coefficients for selection equation

$\varepsilon 2$ random disturbance for unit $\mathrm{i}$ for selection equation. One problem with the two equations (6 and 8) is that the two-stage decision making processes are not separable due to unmeasured farmer variables determining both the discrete and continuous decision thereby leading to the correlation between the errors of the equations. If the errors in equations 1 and 3 are correlated, the estimated variable values determining the level of milk value addition become biased. Therefore, it is important to specify a model that corrects for selectivity bias while estimating the determinants of the level of participation. Hence, Lambda (LBD) was included as one of the independent variables in the farmers' participation decision on milk value addition. The second stage involves including the Mills Ratio (MR) to the volume of milk value addition equation and estimating the equation using Ordinary Least Square (OLS). If the coefficient of the 'selectivity' term is significant then the hypothesis that an unobserved selection process governs the participation equation is confirmed. Moreover, with the inclusion of extra term, the coefficient in the second stage 'selectivity corrected' equation is unbiased (Zaman, 2001). Therefore, the level of participation equation with correction for sample selection bias becomes:

$V=X^{\prime} \beta+\lambda\left(\frac{\phi\left(X^{\prime} \beta\right)}{\Phi\left(X^{\prime} \beta\right)}+\varepsilon 2\right.$

Where,

$\frac{\phi(.)}{\Phi(.)}=$ Mills ratio

$\lambda=$ Coefficient on the mills ratio

$\phi=$ standard normal probability density function

$\Phi=$ standard cumulative distribution function

$\varepsilon 3=$ not correlated with $\varepsilon 1, \varepsilon 2$ and other independent variables. Under the null hypothesis of no sample selection, bias $\lambda$ is not significantly different from zero.

$\mathrm{V}=$ level of milk value addition in liter

\subsection{Hypothesis and Definition of Variables \\ Dependent Variables}

Market participation: It is defined as dummy variables that take 1 if the farmers participate in butter and cheese marketing 0 if not.

Intensity of market participation: It is defined as the quantity of butter and cheese measured in KG. Therefore, intensity of market participation is dependent and continuous variable that represents the level of farmers' participation in marketing of butter and cheese products.

\section{Independent variables}

Age of the household head (AGEHH): It is the continuous variable which can be counted by the number of years dairy producer households lived. Households with aged members consume milk in fluid form and it will be expected that farmers' participation decision and level of participation may be associated both positively and negatively with age of the household.

Family size (FMSIZE): Family size of a respondent is a continuous variable measured in number of family members in the household. Family size with dependent age group can affect negatively market participation of farmers in butter and cheese because large portion of milk is consumed in the form of liquid.

Gender (GNDER): Dummy variable which will take the value 1 for male and 0 for female. The daily decision on how to allocate milk is decided by the woman head of household. It affects farmers' participation decision and level of participation in butter and cheese marketing positively.

Education level of the household (EDULHH): It is a continuous variable which is measured as illiterate, primary, secondary and high school. Education will positively affect decision of dairy products marketing.

Access to credit (ACCREDIT): Dummy variable which can take the value 1 if there is access to credit and 0 if not and positive impact on both farmers participation decision on milk value addition and adoption of improved dairy breed to increase milk production. Access to credit would enhance the financial capacity of the farmer to purchase the improved dairy cows, thereby increasing milk production and enhances farmer participation decision and level of participation of milk value addition thereby increases the level of dairy products marketing. 
Access to market (ACSMCCETR): It is dummy variable which will take the value 1 if there is access to market and 0 otherwise. Accessibility of markets which has a demand for differentiated dairy products initiates farmers to add value to their products. In this case it contributes to the farmers' to participate in milk value addition and enhances the level of participation. Availability of markets with good price for value added dairy products contributes for the decision making on dairy products.

Distance nearest to market (DCEMKT): It is continuous variable, which can be measured by the number of km from the production point to the final sale market. If the household produces dairy products near to the market, it enhances farmers to generate income from the products by reducing transportation cost. As farmers' distance nearest to urban center in $\mathrm{km}$, farmers' likelihood to add values to milk decreases because farmers will be sold their milk in the form raw (Tadele et al., 2013). .

Access to extension service (ACEXSRVCE): It is a dummy variable taking a value of one if dairy producer household has access to extension service and zero otherwise and representing extension services as a source of information on technology. In this line, study conducted by Holloway (2002) identified that extension visit was directly related to dairy household milk market entry decision and marketed milk volume.

Consumer preference for butter (CSMRSPNCE): It is a dummy variable taking value 1 if value addition meets consumers' quality preferences and 0 if not. Therefore, milk value addition in response to consumer quality preference is positively associated with farmers' participation decision and level of participation for milk value addition (Berhanu et al., 2011).

Farmers' membership (FCOOPERTV): Is dummy variable which take the value 1 if the farmers are in membership and 0 other wise. According to Shiferaw et al. (2006), collective marketing, allows small-scale farmers to spread the costs of marketing and transportation and improve their ability to negotiate for better prices, and increase their market power.

\section{RESULT AND DISCUSSION}

Milk and milk products were the major income generating and poverty alleviation tools for small holder dairy farmers in the study area. As the result of survey data, the education level of the households $58.7 \%, 20.3 \%, 13.5 \%$, $16.7 \%$ were illiterate, read and write, primary school (1-8) and high school respectively. This revealed that large percent of household were under illiterate with low perception for milk value addition. Average age of household head was 42 years; dominated by younger heads that encourage milk value addition participation decision of farmers. The maximum and minimum family size of the respondents was 8 and 3 respectively. Thus, average family sizes of sample producers during survey were 6 . In further, the result reveals that the major income source of the farmers are crop-livestock and crop production which accounts $99.2 \%$ and $0.8 \%$ respectively. An average land size of sample respondents is 1 ha per households in Loma Woreda. Thus, the average numbers of milking cows per household is 3 in study area. Three liters of milk, out of average 5 liters yield per day was used for value addition. The major milk value added products produced are butter and cheese.

Table 2: The mean values and standard error results of continuous variables

\begin{tabular}{lllllll}
\hline Variables & $\begin{array}{l}\text { Participants } \\
\text { Mean }\end{array}$ & Stad & $\begin{array}{l}\text { Non participants } \\
\text { Mean }\end{array}$ & $\begin{array}{l}\text { Stad } \\
\text { error }\end{array}$ & $\begin{array}{l}\text { Mean } \\
\text { Mead }\end{array}$ & $\begin{array}{l}\text { Stad } \\
\text { error }\end{array}$ \\
\hline Age & 42 & 1.1 & 46.3 & 1.8 & 44.15 & 0.76 \\
Family size & 6 & 0.17 & 5 & 0.26 & 5.5 & 0.15 \\
Land size & 1 & 0.037 & 1 & 0.06 & 1 & 0.03 \\
Distance nearest to market & 9 & 0.6 & 11 & 1.13 & 10 & 0.54 \\
Milk yield produced per day & 5 & 0.082 & 2 & 0.05 & 3.5 & 0.07 \\
milk yield processed to butter and cheese to & 3.5 & 0.09 & 1.82 & 0.07 & 2.66 & 0.11 \\
supply market & & & & & & \\
Number of dairy cows & 3 & 0.9 & 1 & 0.35 & 2 & 0.6 \\
Dairy farming experience the household & 12 & 6 & 7 & 3 & 9.5 & 4.5 \\
\hline
\end{tabular}

Source: Own survey result (2017) 
Table 3: Access to service and infrastructure to sampled households of producers $(\mathrm{N}=138)$

Variables

Access to extension service

Access to credit

Access to market information

Access to market center

VA extends shelf life of the product

Membership of farmers cooperative

Access to milk collection center

Source: Own survey result (2017)

According to the survey result, out of 138 sample households, $36 \%$ revealed that value added dairy products in market not meet the consumers' preference. Thus, in study area most of dairy producers add value on milk traditionally through indigenous knowledge. Still there is extension service gap on milk value addition in study area. Out of 138 sampled households, $48 \%$ revealed that there was a lack of extension service on milk value addition. According to the result obtained by the respondents' survey from the study area, $73.9 \%$ of sample respondents were faced with limited supply of credit. Milk is processed in to butter and cheese for the purpose of income generation and consumption. Thus, milk is processed and marketed by women only in study area. Respondents from the study area revealed that the reason they process milk is to fetch good price and to extend the shelf life of the products which accounts $64 \%$ and $36 \%$ respectively. Dairy production is labor intensive and the result of respondent survey shows that $100 \%$ of labor source of the producers for dairy production family labor. In study area farmers have faced with the problem of infrastructure such as access to main road for market center and transport facility.

Table 4: Income contribution of dairy sector compared to other sectors in study area

\begin{tabular}{|c|c|c|}
\hline S.No. & Source of income for farmers $2016 / 17 /$ Year & ETB \\
\hline 1 & Sales of dairy products & 4,000 \\
\hline 2 & Sales of Sheep and goats & 6,000 \\
\hline 3 & Beekeeping & 1,800 \\
\hline 4 & Sales from coffee & 3,000 \\
\hline 5 & sales from cereal crop & 2,500 \\
\hline & Total & 14,600 \\
\hline
\end{tabular}

Source: Own survey result (2017)

As the result indicated in Table 6, the major sources of income for producers in study area are sheep and goat, dairy products, coffee, cereal crops and beekeeping respectively.

\subsection{Econometrics Results}

James Heckman has proposed Heckman two-step estimating procedure. In step 1, probability of producers' participation decision on milk value addition was estimated and which is done on the basis of the probit model. In step 2, we estimate the model by adding to it a variable (called the inverse Mills ratio or the hazard rate) that is derived from the probit estimate. Depending on mean; value chi-square test and t-test used to identify the significance difference between frequency of dependent variable and independent dummy variable; and dependent variable and continuous variable respectively. To analyze determinants of participation decision and level of participation, data from 138 households were used. However, only 110 households added values to milk indicating that milk production is not necessarily for value addition, given a household demand for fluid milk consumption. Table 5: The result was estimated by binary probit model (first stage).

\begin{tabular}{lllll}
\hline Variables & Coefficient & Standard error & $\mathrm{P}>/ \mathrm{z} /$ & Marginal effect \\
\hline AGEHH & -0.004 & 0.010 & 0.650 & 0.000 \\
GNDER & 0.570 & 0.210 & 0.040 & 0.060 \\
EDULHH & 0.089 & 0.200 & 0.570 & 0.020 \\
FMSIZE & -0.023 & 0.100 & 0.010 & 0.015 \\
TPSBRED & -0.600 & 0.110 & 0.000 & 0.290 \\
ACCREDIT & 0.700 & 0.400 & 0.050 & 0.157 \\
ACEXSRVCE & 0.600 & 0.300 & 0.020 & 0.138 \\
MLKYLDd & 0.560 & 0.260 & 0.060 & 0.490 \\
Constant & -1.000 & 1.090 & 0.300 & -
\end{tabular}

Number of observations $=138$, LR chi2 $(14) \quad=\quad 34.26$, Probability $>$ chi $2=0.0000$, Log likelihood $=-54$;

Pseudo $\mathrm{R}^{2}=0.18$

Source: Own survey result (2017) 
As the result indicated in Table 8 above, Heckman first stage analysis results are significantly influencing the farmers' market participation decision. The probit model overall goodness of fit for parameters is predicted the observations at $95 \%$ of confidence interval. The model chi-square tests indicate that the overall goodness of fit of the probit model which is $\mathbf{3 4 . 2 6}$ and statistically significant at a probability of less than $1 \%$. This shows that jointly the independent variables included in the probit model regression explain the variations in the farmers' probability market participation decision to butter and cheese. The pseudo-R2 values indicate that the independent variables included in the regression explain significant proportion of the variations in the dairy farmers ${ }^{\text {ec }}$ likelihood to add values to milk or market participation. Thus, pseudo- $\mathrm{R} 2=\mathbf{0 . 1 8}$ indicates that about $18 \%$ of the variation in the dependent variable is due to the explanatory variables included in the model.

Gender (GENDER): This is a dummy variable which take 1 for men households and 0 for women households. Gender has positive relationship with farmers' participation decision on market participation and statistically significant at probability of less than 5\%. Thus, considering of the role of women in milk value addition and market participation of value added dairy products particularly butter and cheese at farm level increases the farmers' participation decision on market participation by $6 \%$.

Family Size (FMSIZE): Family size of a respondent is a continuous variable measured in terms of number of family members in the household. Average number of family size in study area was 5 and most of sampled dairy households are under dependent age group. Thus, milk is consumed at households' level. The result of survey revealed that family size had negative impact on farmers' market participation decision and statistically significant at probability less than $5 \%$. It implies that a unit increase on family size greater than 5 but dependent age group declines farmers' participation decision on market participation by $1.5 \%$. The result agreed with Berem et al. (2010) asserts that household with adult has a positive influence on the both farmers likelihood to add and extent of value addition thereby market participation, implying that higher the number of adults in a household, the higher the value addition done by the household thereby increases the farmers market participation. This might be related to the decisions being made.

Types of dairy cows owned (TPSBRED): Dummy variable which take 0 for local breed and 1 for exotic. Types of breed of dairy cows had negative effect and statistically significant at the probability less than $1 \%$. This implies most of sampled households in study area have local breed of dairy cows. These local breed of dairy cows were low in milk production. Thus, little amount of milk left for value addition purpose as well as producers' market participation become low. The marginal effect realizes that households only owning of local dairy cows decline farmers' market participation decision on butter and cheese by $29 \%$.

Access to credit (ACCREDIT): It is a dummy variable which take value 1 if farmers have access to credit service and 0 otherwise. Access to credit had positive impact on milk value addition decision of producers and statistically significant at probability of 5\%. Access to credit encourages probability of farmers' market participation and milk value addition by $15.7 \%$. The reason may be farmers could purchase dairy cows, milking equipment, packaging materials and others easily if and only if they get access to credit.

Access to extension service (ACEXSRVCE): It is a dummy variable which take value 1 if farmers have access to extension service and 0 otherwise. Access to extension service had positive impact and statistically significant at probability less than $5 \%$. This implies that access to extension service of dairy households create awareness on milk value addition and improves producers participation decision by $13.8 \%$. The result agreed with Holloway and Ehui (2002) found that extension visits directly related with dairy household production, milk value addition and marketing of butter and cheese.

Milk yield produced at household per day (MLKYLD): It is a continuous variable which measures the quantity of milk produced in liter. Quantity of milk yield produce at household had positive effect and statistically significant at probability less than $10 \%$. The marginal effect revealed that a liter increase in milk yield from local breed at household level increases milk value addition participation and marketing by $49 \%$. The reason may be farmers in study area adopted with local breed of dairy cows and thus local breed had low production of milk but better in fat content of butter. This study is in line with Tadele et al. (2013) studied that keeping of more local breed and producing more milk yield enhances both milk value addition decision and level of participation decision on milk value addition as well as marketing. The result also agreed with Borem et al. (2010) reveals that farmers with larger quantities of honey are more likely to engage in value addition as they see it as profitable unlike their colleagues who harvest smaller quantities of honey. 
Table 6: Determinants of intensity of farmers' participation in butter and cheese marketing

\begin{tabular}{llll}
\hline Variables & Coefficient & Standard error & $\mathrm{P}>/ \mathrm{z} /$ \\
\hline AGEHH & 0.000 & 0.002 & 0.570 \\
GNDER & 0.660 & 0.320 & 0.020 \\
EDULHH & 0.047 & 0.030 & 0.091 \\
FMSIZE & -0.036 & 0.100 & 0.580 \\
TPSBRED & 0.290 & 0.200 & 0.030 \\
ACCREDIT & 0.230 & 0.060 & 0.026 \\
ACEXSRVCE & 0.140 & 0.050 & 0.000 \\
ACSMCCETR & 0.480 & 0.300 & 0.780 \\
DCEMKT & -0.010 & 0.010 & 0.033 \\
MLKYLDd & 0.487 & 0.810 & 0.000 \\
FCOOPERTV & 0.130 & 0.670 & 0.090 \\
LABOR & 0.300 & 0.300 & 0.340 \\
ACCSMKTINF & 0.090 & 0.300 & 0.680 \\
CSMRSPNCE & 1.100 & 0.280 & 0.000 \\
Constant & -1.340 & 1.00 & 0.300 \\
Mills ratio & 0.200 & 0.100 & 0.040 \\
\hline
\end{tabular}

Number of observation $=138$, Censored observation $=28$, Uncensored observation $=110$, Wald chi2 $(13)=$ 1460.54 (0.0000), Prob $>$ chi2 $=0.0000$, Rho=0.7, Sigma $=0.5$.

Source: Own survey result (2017)

The second stage Heckman selection estimates for extent of producers participation in butter and cheese marketing indicated as Table 9. Wald Chi-Square test employing an appropriate degree of freedom which implies that the overall goodness of fit for the Heckman selection model is statistically significant at less than $10 \%$. Sigma indicates the adjusted standard error for the farmers' participation decision on level of butter and cheese marketing regression while Rho indicates that the correlation coefficient between the unobservable that determine selection into farmers' participation decision and the unobservable that determine the level of participation decision on butter and cheese marketing. Rho positive indicates the unobservable in the selection of participation decision of butter and cheese marketing are also affecting the stage 2 model (level of milk value addition and marketing) and is positively correlated. Thus, Wald chi2 (13) is strongly significant reveals that Heckman two stage model is applicable for this study.

GNDER (Gender): It is a dummy variable which take 1 for men households and 0 for women households. Gender has positive relationship with farmers' participation decision on level of butter and cheese marketing thereby statistically significant at probability less than $5 \%$. Thus, taking the issue of gender under consideration increases the level of milk value addition by 0.66 liter. The result of sampled respondents confirmed that most of the activities like feeding, watering, processing, barn cleaning, packaging and marketing dairy products were performed by women. The result of this study agreed with that of Tadele et al. (2014) reported that males are more mobile and have a chance to collect information on different value added dairy products than selling raw milk.

Educational level of household (EDULHH): It is the continuous variable measured as illiterate, read and write, primary, secondary and certificate. It has positive relation with farmers' participation decision on level of milk value addition and statistically significant at the probability less than $10 \%$. Improving the education level of the households by keeping other independents constant increases the level of milk value addition participation of farmers by 0.05 liter. The reason might be education enhances the skills of farmers on milk value addition.

Distance nearest to market (DCEMKT): It is continuous variable and measured by $\mathrm{km}$. As expected, distance to the nearest market center is statistically significant at the probability less than $5 \%$ and negatively associated with farmers' participation decision on level of milk value addition. A unit nearest to market center declines the level of milk value addition by 0.01 . The reason might be milk can be consumed in the form of liquid.

Access to extension service (ACEXSRVCE): It is a dummy variable which takes 1 if farmers have access to extension service and 0 otherwise. Access to extension service has positive relation with farmers' participation decision on level of milk value addition and statistically significant at the probability less than 5\%. The result of sampled households' survey realizes that improving of access to extension service increases the level of milk value addition by 0.14 liter while keeping other independent variables constant. Access to extension service enhances the level of milk value addition of farmers. The result agreed with Tadele et al. (2014) asserts that access to extension service widens the actors' knowledge and enhances the farmers' participation decision on milk value addition and level of milk value addition.

Types of dairy cows owned (TPSBRED): Dummy variable which take 0 for local breed and 1 for exotic. Types of breed of dairy cows had negative effect and statistically significant at the probability less than 5\%. This implies most of sampled households in study area have local breed of dairy cows. These local breed of dairy cows were low in milk production. Thus, little amount of milk left for value addition purpose. By keeping other variables 
constant additional owning of local breed of dairy cows increases the level of milk value addition by 0.3 liter. Access to credit (ACCREDIT): It is a dummy variable which takes 1 if farmers who access to credit and 0 other wise. Access to credit has positive impact on level of milk value addition and significant at probability less than $5 \%$. Keeping other independent variables constant, access to credit raises the level of milk value addition by 0.23 liter. This finding coincides with that of Owuor \& Bebe (2009) that participation in credit has been found to cause a rise in household income in the long-run this rise in income is likely to have a positive effect on the probability to add value and level of value addition thereby market participation.

Membership in farmers cooperative (FCOOPERTV): It is a dummy variable which take 1 for household head who are in farmers group and 0 for others. It is positively associated and statistically significant at probability less than $10 \%$. Keeping other independent variables constant household head being in farmers group enhances the farmers' participation decision on the volume of milk value addition by 0.13 liter. This is because of farmers' in group have access to training on easy access to skills, credit and information which in turn enable them to improve milk value addition in farm level to get better price did single farmers.

Quantity of milk yield (MLKYLDd): This is a continuous independent variable which is measured in litter and has positive impact and statistically significant at probability less than $1 \%$. This implies that by keeping other independent variables constant one additional liter of milk increases the level of milk value addition by 0.49 liter. The result revealed that in study area sampled households owned with local breed dairy cows which have low milk production capacity. Thus, a little amount of milk left for value addition purpose. By keeping other independent variables constant additional liter of milk necessary to enhance the extent of milk value addition to get more value added dairy products. The result of this study agreed with Borem et al. (2010), asserts that farmers with larger quantities of honey are more likely to engage in value addition as they see it as profitable unlike their colleagues who harvest smaller quantities of honey. This factor was reported as a major constraint to value addition with those who harvested little amounts reporting that they could not participate in value addition majorly because they viewed it as a waste of time and finances.

Consumers' quality preference (CSMRSPNCE): It is a dummy variable which had positive impact and statistically significant at the probability of less than $1 \%$. This implies that by keeping other explanatory variables constant an addition of sampled households add value on milk response to consumers' quality preference encourages the likelihood of farmers' extent to milk value addition by 1.1 liter. According to Colbon and Menapace (2011), it is important for agro-food distributors to understand the psychological construct underlying consumers' purchase decision process. The result coincides with that of Berhanu et al. (2011) asserts that while keeping other explanatory variables constant, an addition of a respondent household who add values to milk in response to consumer quality preference increases in the level of participation.

Lambda : According to Heckman two stage model output, the lambda (Inverse Mills Ratio) or selectivity bias correction factor has a positive impact and statistically significant at probability less than 5\%. This result suggests that there appears to be unobserved factors that might affect both the probability of producers' participation decision and level of participation on butter and cheese marketing in study area. The coefficient of Mills ratio in the Heckman two-stage estimation is $\mathbf{0 . 0 4}$ which is significant at the probability of less than $5 \%$ realizes that there is sample selection bias and the presence of unobservable behaviors of producers determining both producers' likelihood to milk value addition and level of participation on milk value addition in study area.

\section{SUMMARY CONCLUSSION AND RECOMMENDATIONS}

\subsection{Summary and Conclusion}

This study was aimed with specific objectives of analyzing the determinants of farmers' market participation decision and level of participation along butter and cheese value chain at farm level. Thus, data were gathered from both primary and secondary sources. The primary data for this study were collected from 138 producers from Loma Woreda, Dawuro Zone Southern Ethiopia. Both descriptive statistics and econometric model used by SPSS and STATA software packages. According to the result obtained; input suppliers, producers, local collectors, whole sellers, and retailers were direct actors along butter and cheese value chain in study area. Out of 138 respondents, $85 \%$ revealed that the main reason for most farmers not participating in credit were limited supply of credit, bureaucracy, unavailability of credit agents and high interest payment especially to take credit from Omo micro finance institution.

According to the result obtained through the operation of Heckman two stage models, the model chi-square tests indicate that the overall goodness of fit of the probit model which is $\mathbf{3 4 . 2 6}$ and statistically significant at a probability of less than $1 \%$. This shows that jointly the independent variables included in the probit model regression explain the variations in the farmers' probability to add values to milk. Accordingly, farmers' participation decision on market participation positively associated with gender, quantity of milk yield produced per day, access to extension service, access to credit and statistically significant at probability $5 \%$, less than $10 \%$, $5 \%$, and $5 \%$, respectively where as types of dairy cow breed owned by households and family size are negatively associated with farmers' market participation decision and statistically significant at probability less than $10 \%$ and 


\section{$5 \%$ respectively.}

The second stage Heckman selection estimates for extent of producers' participation in butter and cheese marketing. Thus, Wald Chi-Square test employing an appropriate degree of freedom which implies that the overall goodness of fit for the Heckman selection model is statistically significant at less than $10 \%$. According the result obtained from the producers, gender, education level, access to extension service, access to credit, membership in farmers' cooperatives, quantity of milk produced and consumers' quality preference in study area were affect the volume of market participation positively and statistically significant at probability less than $5 \%, 10 \%, 5 \%$, $5 \%, 10 \%, 1 \%$ and $1 \%$ respectively while family size and distance nearest to market were negatively associated with level of farmers' market participation of butter and cheese and statistically significant at probability less than $5 \%$ and 5\% respectively. Finally, the result obtained from the respondents reveals that the coefficient of Mills ratio in the Heckman two-stage estimation is 0.04 which is significant at the probability of less than $5 \%$ realizes that there is sample selection bias and the presence of unobservable behaviors of producers determining both producers' likelihood to farmers' market participation of butter and cheese as well as level of participation in study area.

\subsection{Recommendations}

Based on the result obtained from the current study the following are expected to be done for the further improvement of butter and cheese value chain in the study area. Training of producers on milk value addition and using of technology like adoption of improved dairy cow breed to increase the quantity of milk the most critical areas. Generally, handling of dairy products to increase consumers preference towards value added milk products are key to the development of the dairy value chain thereby improving butter and cheese production system. Intensification of agricultural extension service in dissemination of improved dairy cows breed, technical service provision, strengthening of access to credit are most important. Farmers' membership in cooperative is quite important for creation of training, market information, pooling of resources for the intensive involvement of farmers' in dairy sector to benefit them more. In addition to this, provision of improved milk churning equipments, infrastructure like road should be provided for farmers. Creating marketing network among actors is quite important for value chain coordination, innovation and development. In general, policy initiatives aiming at increasing farmers' access to dairy technologies, improving market information, road, access extension service, access to credit and cooperative development are recommended to step up the development of dairy sector particularly butter and cheese value chain in the study area. Further examining on economic analysis of fluid milk consumption at household level and butter and cheese marketing at farm level in-depth and determinants of farmers' participation decision and extent of participation in cheese marketing in commercialized way for along the whole value chain should get attention.

\section{REFERENCES}

Anandajayasekeram, P., \& Gebremedhin, B. (2009): Integrating innovation systems perspective and value chain analysis in agricultural research for development: Implications and challenges (No. 16). ILRI (aka ILCA and ILRAD).

Berem, Risper M.; Obare, G.; Owuor, G. (2010). Is value addition in honey a panacea for poverty reduction in the Asal in Africa? Empirical evidence from Baringo District, Kenya. In Contributed Paper presented at the Joint 3rd African Association of Agricultural Economists (AAAE) and 48th Agricultural Economists Association of South Africa (AEASA) Conference, Cape Town, South Africa.

CSA (Central Statistical Authority) (2009). Central Statistical Authority. Addis Ababa, Ethiopia.

CSA (Central Statistical Authority) (2012). Ethiopia Sample survey Enumeration. Addis Ababa, Ethiopia

Felleke, G. (2003): Milk and dairy products, post-harvest losses and food safety in Sub-Saharan Africa and the near east. A review of the small scale dairy sector-Ethiopia. FAO Prevention of Food Losses Programme. FAO, Rome, Italy.

Getinet, H. (2009). The impact of global economic and financial crises on the Ethiopian dairy industry.

Gujarati, D. (2003). Basic Econometrics. $4^{\text {th }}$ edition. Tata McGraw-Hill Publishing Company Limited, New Delhi, India. P.614

Hawkes, C. and M.T. Ruel. (2011). Value Chains for Nutrition. 2020 Conference Paper 4, prepared for the IFPRI 2020 International Conference "Leveraging Agriculture for Improving Nutrition and Health", February 1012, New Delhi, India.

Heckman J. J. (1979). "Sample Selection Bias as a Specification Error" Econometrics 47(1): 153-161.

Jabbar, M. A. (2010): Policy barriers for dairy value chain development in Bangladesh with a focus on the northwest region. CARE Bangladesh.

Kuma, B., Getnet, K., Baker, D., \& Kassa, B. (2011). Determinants of participation decisions and level of participation in farm level milk value addition: The case of smallholder dairy farmers in Ethiopia.

Lemma, T., Tegegne, A., Puskur, R., \& Hoekstra, D. (2008). Moving Ethiopian smallholder dairy along a sustainable commercialization path: missing links in the innovation systems. 
LDMPS (2007): Phase Report - Data Collection and Analysis Volume I - Dairy. GRM International BV.

LMD Research Interviews and Reports (2013): Unpublished research documents from LMD Research, 2012-13

MoA (2010): Ethiopia Animal Health Year Book (2009/10). Addis Ababa: Federal Ministry of Agriculture Animal and Plant Health Regulatory Directorate (APHRD).

MoFED, 2009: Sustainable Development and Poverty Reduction Program. Addis Ababa Ethiopia

Tadele, M., Tewodros, T., and Noreen, B., 2014. Factors influencing urban and per-urban dairy producers' participation in milk value addition and volume of milk value added in Welmera Woreda, West Shewa Zone of Oromia Regional State of Ethiopia. International Journal of Livestock Production, 5(9), 165-172.

Yitaye, A., Wurziger, M., Azage, T., Zollitsch, W. (2007). "Urban and peri-urban farming systems and utilization of the natural resources in the north Ethiopian highlands." Proceedings of Conference on International Agricultural Research for Development. 